\title{
Sprawozdanie z Ogólnopolskiej Konferencji Naukowej nt. „Zachować dla przyszlości. Sprawy oświaty, edukacji i nauki w przekazie prasowym XIX i XX wieku"
}

DOI: 10.14746/BHW.2016.35.14

W dniach 14-15 listopada 2016 r. na Uniwersytecie Łódzkim odbyła się Konferencja Naukowa nt. „Zachować dla przyszłości. Sprawy oświaty, edukacji i nauki w przekazie prasowym XIX i XX wieku"1, którą zorganizowała Katedra Historii Wychowania i Pedeutologii Wydziału Nauk o Wychowaniu. Patronat nad konferencją objęło Towarzystwo Historii Edukacji.

Na Konferencję do Łodzi przybyli nie tylko historycy wychowania, ale także pedagodzy, prasoznawcy, bibliolodzy oraz przedstawiciele innych dyscyplin naukowych. Uroczystego otwarcia obrad dokonał prof. nadzw. dr hab. Grzegorz Michalski - Kierownik Katedry Historii Wychowania i Pedeutologii UŁ. Po powitaniu zebranych gości, przypomniał, że kolejny już zjazd uczonych z całej Polski prowadzących badania nad czasopiśmiennictwem został poświęcony Pamięci Mistrzów: prof. Eugenii Podgórskiej i prof. Tadeusza Jałmużny, w dziesiątą rocznicę ich śmierci Po przedstawieniu roli, jaką odegrali w wypracowaniu merytorycznego kształtu łódzkiego ośrodka badań historyczno-pedagogicznych, wskazał, że dzięki ich wysiłkowi i nakreślonym z prospektywną wyobraźnią planom naukowym zespół łódzkich historyków wychowania kontynuuje najlepsze polskie tradycje badawcze. Koncentrując się na prasowej działalności wydawniczej, zauważył, że należy ona do jednego z ważniejszych rodzajów aktywności ludzkiej, ponieważ jej wytwory są istotnym środkiem podnoszącym poziom kultury i edukacji społeczeństwa. Omawiając potrzebę debaty naukowej nad rekonstrukcją zawartości periodyków, podkreślił, że dla historyków wychowania szczególnie ważny jest wiek XIX i XX, ponieważ te stulecia zaznaczyły się dynamicznym wzrostem prasowej produkcji edytorskiej, w której znaczący udział miały czasopisma służące upowszechnianiu i popularyzacji wiedzy, profesjonalizacji zawodu nauczyciela i wychowawcy, pomocy uczniom w edukacji szkolnej, a także wspieraniu rodziców w wychowaniu dzieci.

W następnej kolejności głos zabrała Dziekan Wydziału Nauk o Wychowaniu UŁ prof. nadzw. dr hab. Danuta Urbaniak-Zając, która w swoim wystąpieniu wyraziła pogląd, że wyniki badań w zakresie historii wychowania stanowią źródło naukowych inspiracji dla pedagogów, gdyż każde współczesne zjawisko edukacyjne i oświatowe ma swoje korzenie w przeszłości, niekiedy bardzo odległej. Wyrażając zadowolenie z udziału w łódzkiej Konferencji przedstawicieli historyków wychowania niemal ze wszystkich ośrodków akademickich w kraju, życzyła zebranym udanych merytorycznie obrad oraz pasjonujących dyskusji. Następnie wystąpiła Prezes Towarzystwa Histo-

\footnotetext{
${ }^{1}$ Konferencja ta była już trzecim spotkaniem naukowym na Uniwersytecie Łódzkim, które poświęcono problematyce czasopiśmiennictwa. Pierwsze odbyło się w październiku 2009 r., kolejne w październiku 2011 r. Warto zauważyć, że tematykę związaną z przekazem prasowym dotyczącym oświaty i edukacji poruszano również na konferencjach w Łodzi w 2012 i 2014 r., podczas których głównym przedmiotem wystąpień i dyskusji była działalność wydawnicza w XIX i XX w.
} 
rii Edukacji - prof. zw. dr hab. Dorota Żołądź-Strzelczyk, kierując do uczestników Konferencji słowa zachęty do dalszych odkryć naukowych dotyczących problemów oświaty i edukacji, o których rozważano na łamach dziewiętnasto- i dwudziestowiecznych periodyków.

W konferencji udział wzięli przedstawiciele wielu placówek naukowych m.in. z: Uniwersytetu Mikołaja Kopernika w Toruniu, Uniwersytetu Gdańskiego, Uniwersytetu im. Adama Mickiewicza w Poznaniu, Uniwersytetu Wrocławskiego, Uniwersytetu Opolskiego, Akademii Pedagogiki Specjalnej w Warszawie, Uniwersytetu Pedagogicznego im. KEN w Krakowie, Uniwersytetu Warszawskiego, Uniwersytetu Jana Kochanowskiego w Kielcach, Państwowego Uniwersytetu Pedagogicznego im. I. Franki w Drohobyczu, Uniwersytetu Kardynała Stefana Wyszyńskiego, Uniwersytetu w Białymstoku, Politechniki Białostockiej, Akademii Ignatianum w Krakowie, Uniwersytetu Gdańskiego, Uniwersytetu Zielonogórskiego, Niepaństwowej Wyższej Szkoły Pedagogicznej w Białymstoku, Uniwersytetu Warmińsko-Mazurskiego w Olsztynie, Uniwersytetu Kazimierza Wielkiego w Bydgoszczy, Uniwersytetu Szczecińskiego, Akademii Wychowania Fizycznego i Sportu w Gdańsku, Towarzystwa Kultury Języka w Warszawie, Oddział w Łomży, Uniwersytetu Marii Curie-Skłodowskiej w Lublinie, Archiwum Państwowego w Kielcach, Oddział w Sandomierzu, Uniwersytetu Łódzkiego, Uniwersytetu Rzeszowskiego, Biblioteki Uniwersyteckiej w Poznaniu, Biblioteki Uniwersytetu Łódzkiego oraz Miejskiej Biblioteki Publicznej im. Adama Asnyka w Kaliszu.

Bogata problematyka naukowa konferencji podzielona została na dwa dni, w trakcie których odbyły się 2 sesje plenarne i 7 sekcji tematycznych. W pierwszym dniu konferencji, podczas sesji plenarnej, wystąpiła prof. zw. dr hab. Dorota Żołądź-Strzelczyk, przedstawiając prasę przełomu XIX i XX wieku jako źródło do badania zabawek dziecięcych. W dalszej kolejności prof. zw. dr hab. Eleonora Sapia-Drewniak omówiła problemy edukacji ludności polskiej przedstawione na łamach „Głosów znad Odry”. Rozważania dotyczące szkolnictwa na Kresach Wschodnich w II RP w świetle prasy zaprezentowała prof. nadzw. dr hab. Hanna Markiewiczowa. W drugiej części obrad plenarnych swój referat zaprezentował prof. zw. dr hab. Krzysztof Woźniakowski, ukazując wątki szkolnictwa, oświaty i nauki na łamach lwowskiej „Czytelni dla Młodzieży”, następnie prof. nadzw. dr hab. Agnieszka Wałęga przedstawiła problem edukacji i wychowania kobiet na kartach galicyjskiej „Szkoły”, a na zakończenie prof. nadzw. dr hab. Katarzyna Dormus rozważała o wzorowym modelu szkoły polskiej na łamach galicyjskich pism kobiecych u progu niepodległości. Uwieńczeniem pierwszej sesji plenarnej była dyskusja dotycząca najważniejszych zagadnień przedstawionych przez referujących.

W tym samym dniu, odbyły się trzy sekcje tematyczne. Na pierwszej z nich zaprezentowano czasopisma, których wydanie przypadało na wiek XIX, należały do nich periodyki: „Szkoła Polska”, „Szkółka dla Dzieci”, „Szkółka dla Młodzieży” (dr Marta M. Kacprzak), "Wielkopolanin” (dr Katarzyna Kabacińska-Łuczak), „Przyjaciel Sług” (dr Izabela Krasińska), prasa zaboru rosyjskiego (dr Teresa Gumuła), „Gniazda Sieroce” (dr Oresta Karpenko i dr Piotr Sławiński), „Świt” (dr Joanna Falkowska), „Dietskij wiestnik” (prof. Magdalena Dąbrowska), „Siewiernaja pczeła” (dr Piotr Głuszkowski), wybrane czasopisma galicyjskie (dr Dorota Grabowska-Pieńkosz), „Dziennik Łódzki” 
(prof. Grzegorz Michalski), „Przewodnik Higieniczny”(dr Elżbieta Dolata), łódzka prasa z lat rewolucji 1905-1907 (dr Kamil Śmiechowski).

W drugiej sekcji tematycznej przedstawiano czasopisma z początków XX w., najczęściej była to prasa drukowana w okresie międzywojennym: łódzkie jednodniówki (dr Joanna Sosnowska), „Myśl Karaimska” (dr Urszula Wróblewska), „Słowa” (dr Andrzej Smolarczyk), „Ilustrowana Republika” (prof. Iwonna Michalska), „Szkoła i Nauczyciel” (prof. Wiesława Leżańska), „Miesięcznik Katechetyczny i Wychowawczy” (dr Anna Królikowska), „Wychowanie Przedszkolne” (dr Aleksandra Feliniak), „Ziemianka Polska” (mgr Agnieszka Kaźmierczak), „Ruch Charytatywny” (dr Edyta Bartkowiak) „Liskowianin” (mgr Monika Sobczak-Waliś), „Świat Zwierzęcy”(prof. Edyta Wolter).

W ostatniej sekcji tematycznej, która odbyła się pierwszego dnia konferencji, zaprezentowano powojenną prasę i zawarte w niej myśli o wychowaniu. Do przykładowych czasopism, które omówiono należały: „Kwartalnik Filmowy” i „Poradnik Muzyczny” (dr Marzena Kowalska, dr Irena Łabiszewska), „Komunikaty Mazursko-Warmińskie” (dr Andrzej Puliński), prasa lokalna Warmii i Mazur (dr Urszula Pulińska), „Rocznik Andragogiczny” (dr Katarzyna Jarosz), „Życie Szkoły” (dr Elżbieta Gorloff), „Problemy Opiekuńczo-Wychowawcze” (dr Nella Stolińska-Pobralska), „Rodzina i Szkoła” (mgr Małgorzata Krakowiak), „Edukacja Dorosłych” (dr Joanna Janik-Komar).

Podczas drugiego dnia, obrady realizowano w czterech sekcjach tematycznych. W pierwszych dwóch omawiano materiał zamieszczony w periodykach: „Miesięcznik Połocki” (dr Andrzej Paweł Bieś), „Tygodnik Ilustrowany” (dr Zbigniew Żółciński), dodatkch modowych prasy kobiecej w XIX w. (dr Monika Nawrot-Borowska), „Pobudka” (dr Sabina Kwiecień), „Głos Kamiennej” (dr Edyta Kahl-Łuczyńska), „Higiena Ciała i Sport” (mgr Agnieszka Małek), „Młody Las” (dr Beata Topij-Stempińska), prasie lokalnej Ziemi Łomżyńskiej (dr Elżbieta Chojnowska). W kolejnych sekcjach zaprezentowano materiał prasowy z następujących pism: „Czas” (dr Ewa Barnaś-Baran), „Kalendarz Lubelski” (dr Marzena Okrasa), „Przegląd Zakopiański” (dr Renata Bednarz-Grzybek), „Świat Głuchych” (dr Iwona Czarnecka), periodyków pozytywistów warszawskich (dr Aneta Bołdyrew), „Gniazda Sieroce”(dr Andrzej Kołakowski), polskiej prasy Prus Zachodnich (dr Paweł Śpica), „Mały Ster” (dr hab. Anna Boguszewska).

Konferencję zamknięto sesją plenarną, podczas której zaprezentowano siedem referatów omawiających zagadnienia związane z czasopiśmiennictwem XX w. Prof. nadzw. dr hab. Witold Chmielewski skoncentrował uwagę na periodykach nauczycielskich i pedagogicznych uchodźstwa polskiego z lat 1940-1947, dr hab. Artur Jazdon ukazał problem wydawania i dystrybucji podręczników szkolnych na łamach „Przeglądu Księgarskiego" w okresie międzywojennym, prof. nadzw. dr hab. Piotr Gołdyn przybliżył kwestie pedagogiczne i oświatowe zawarte w dzienniku „Gazeta Kolska” z lat 1931-1939, natomiast prof. nadzw. dr hab. Elżbieta Magiera zanalizowała sprawozdania szkolne gimnazjów międzywojennych, dowodząc, że stanowią one bogate źródło wiedzy o ich działalności.

W ostatniej części obrad plenarnych wystąpiła prof. nadzw. dr hab. Joanna Król, przybliżając problematykę kształcenia nauczycieli na łamach „Wychowania”, natomiast prof. nadzw. dr hab. Justyna Gulczyńska, badając to samo czasopismo, zaprezentowała te 
aspekty wychowania, które przyjmowały wymiar ideologiczny. Z kolei prof. nadzw. dr hab. Jacek Kulbaka omówił periodyk „Szkoła Specjalna”, charakteryzując go jako kwartalnik wydawany w służbie pedagogiki i osób z niepełnosprawnością.

$\mathrm{Na}$ zakończenie konferencji głos zabrał prof. nadzw. dr hab. Grzegorz Michalski, podziękował za udział w Konferencji i prezentację wartościowych merytorycznie referatów, które przyczyniły się do wzbogacenia wiedzy z zakresu historii wychowania. Podkreślił, że naukowe spotkanie w Łodzi udowodniło, że prasa jest nadal bogatym źródłem informacji dla historyków i pedagogów, bo to właśnie na jej łamach odnotowywane są zjawiska i wydarzenia, które często nigdzie indziej nie są zapisane.

Matgorzata Krakowiak 